\title{
Academic Socialization: Understanding Parental Influences on Children's School-Related Development in the Early Years
}

\author{
Lorraine C. Taylor \\ University of North Carolina at Chapel Hill
}

\author{
Jennifer D. Clayton \\ University of South Carolina
}

\author{
Stephanie J. Rowley \\ University of Michigan
}

\begin{abstract}
This review summarizes the research literature on the academic socialization of children within the family context. A conceptual model is introduced that describes the process of academic socialization, including parental experiences in school, parental school-related cognitions, and specific parenting behaviors. Parental attitudes and practices provide the foundation for children's development of schemas about school performance and thus are critical determinants of children's early school experiences. In addition, recent efforts to understand the role of transition practices aimed at facilitating children's early adjustment in school are described. The present review extends the transition practices literature by providing a developmental perspective on parenting influences on children's academic socialization, within an ecological systems perspective. The authors describe academic socialization as a process that occurs under the broad umbrella of socioeconomic and cultural contexts.
\end{abstract}

\begin{abstract}
Although there has been considerable research on the multitude of parental influences that shape the process of child development, less is known about the specific ways in which parents socialize their children in terms of school-related behaviors and outcomes. The extant research suggests that there are critical links between parenting and children's school outcomes, but there is little information available on what we are calling "academic socialization." Academic socialization encompasses the variety of parental beliefs and behaviors that influence children's school-related development. Parents are considered to be the primary agents of child socialization. The process by which parents shape a child's behaviors, attitudes, and social skills so that the child will be able to function as a member of society is broadly encompassed by the term socialization.
\end{abstract}

Lorraine C. Taylor, Department of Psychology, University of North Carolina at Chapel Hill; Jennifer D. Clayton, Department of Psychology, University of South Carolina; Stephanie J. Rowley, Department of Psychology, University of Michigan.

Correspondence concerning this article should be addressed to Lorraine C. Taylor, Department of Psychology, University of North Carolina, CB\#3270, Chapel Hill, NC 27599-3270. E-mail: 1ctaylor@email.unc.edu
Because success in the school setting is valued by society and is viewed as a primary determinant of adult independence and success, understanding the ways in which parents socialize their children about school warrants formal study.

Academic socialization as a formal construct has received only limited attention in the literature, but what has been subject to research is how some parenting behaviors promote positive school experiences for children and other types of parenting hinder children's academic success. In this article, we review the literature on parental influences on young children's schoolrelated development and propose a model that encapsulates the various influences on academic outcomes. A novel feature of this conceptual model is the depiction of the process by which intergenerational influences may shape academic outcomes. Building on the framework outlined in ecological theory and further developed in the contextual systems model, our model provides a heuristic for understanding children's academic socialization.

A myriad of intrafamilial and extrafamilial factors operate in shaping children's developmental trajectories. Bronfenbrenner's (1986, 1989) ecological theory of development cap- 
tures the interplay of these factors, emphasizing the importance of the relationships among systems. The importance of the dynamic interplay of systems in shaping child development is similarly emphasized in the contextual systems model (Pianta \& Walsh, 1996), which specifically focuses on children's academic performance. According to this model, the child-family system and the school system operate in conjunction to shape children's academic outcomes and general school experiences. Understanding and enhancing relationships within and between systems promotes school success for children (Pianta \& Walsh, 1996).

Research on the ways in which parents influence child development may be loosely described as falling into two broad perspectives (Kellaghan, Sloane, Alvarez, \& Bloom, 1993). The "what parents do" perspective emphasizes behavioral features of parent-child relationships and encompasses a number of specific research paradigms. In contrast, the "who parents are" perspective generally focuses on the sociodemographic, biological, and contextual characteristics of individual parents and the ways in which these characteristics correlate with children's academic outcomes. A growing number of research studies combine features of each perspective, but much of the extant literature may be categorized as focusing on one perspective or the other.

The present conceptual model (Figure 1) reflects tenets of ecological theory and the contextual systems model by describing children's academic socialization as taking place under the broader umbrella of socioeconomic and cultural contexts. The model connects the "what parents do" and "who parents are" perspectives and provides a schematic for understanding the multiple influences that shape child development. The model extends the conventional understanding of relationships across the systems of influences by highlighting an important but understudied construct: parents' own experiences in school. We propose this model as one way of conceptualizing parental influences on children's school adjustment and academic outcomes. That is, parents' own working models of school, a combination of recollections of their own school experiences and their attitudes, values, and beliefs about school, influence parenting behaviors with children making the transition to school. In this article, we focus primarily on parental contributions to academic socialization, but the importance of understanding transactional influences is discussed.

We begin by describing the literature on parenting, with an emphasis on the ways in which parents shape their children's academic outcomes. We then discuss the role of parental attitudes and beliefs and detail several specific parental behaviors shown to be predictors of children's academic experiences. We also discuss other overarching influences such as socioeconomic status and culture, as well as the roles of child characteristics and the emerging influences of peer groups.

\section{The "What Parents Do" Perspective}

Socialization by parents shapes the development of children's prosocial and antisocial behaviors (Baumrind, 1991; Maccoby \& Martin, 1983; Thompson, 1993), behaviors that have clear implications for children's success or failure in the school setting. Much of the classic research on parenting focuses on links between parenting typologies or discipline practices and a variety of child outcomes. Findings from this research indicate that "authoritative" parenting behaviors, characterized by high levels of parental warmth, responsiveness, and demandingness coupled with low levels of negativity and conflict, are associated with better academic and social outcomes for children and adolescents across a number of family types, including single-parent families, intact (nondivorced) families, and stepfamilies (Baumrind, 1991; Hetherington, Henderson, \& Reiss, 1999; Hill, 1999; Taylor, 1994). These studies suggest that "authoritarian" parenting, characterized by low levels of warmth and responsiveness and high levels of demandingness and firm control, is associated with maladaptive child and adolescent outcomes.

Although categorizing parenting behaviors into specific typologies is a popular approach, there are questions about the ability of this approach to provide an understanding of cultural or ethnic group differences. Aspects of authoritarian parenting such as the use of firm control and the more frequent use of physical discipline have been associated with negative outcomes among European American children and adolescents. These aspects of authoritarian parenting have been shown to be less predictive 


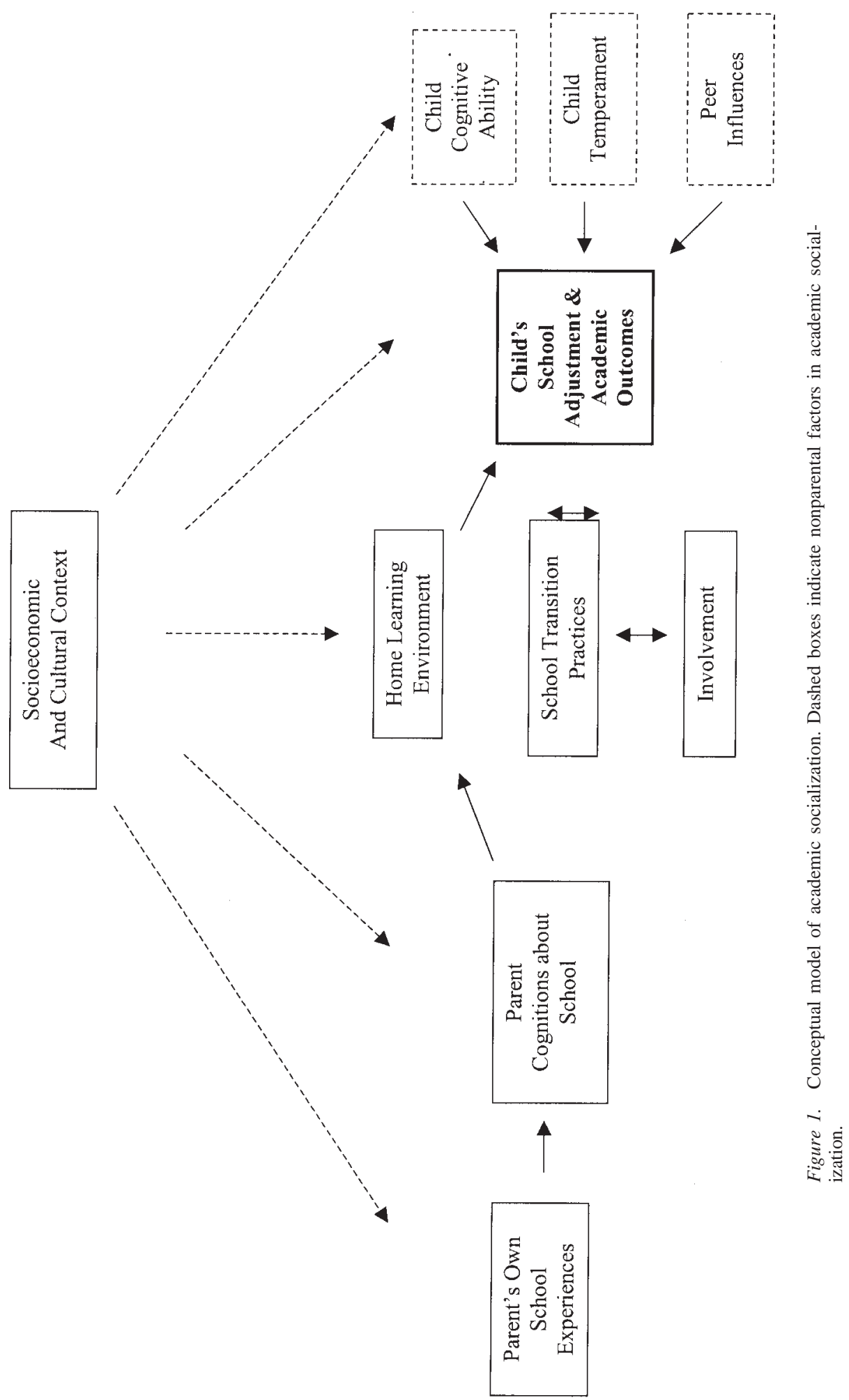


of negative outcomes among African American children and adolescents (Avenevoli, Sessa, \& Steinberg, 1999; Deater-Deckard, Dodge, Bates, \& Pettit, 1996; Gonzales, Hiraga, \& Cauce, 1998), suggesting that the cultural context in which parenting occurs is an important consideration for understanding how parenting influences child and adolescent outcomes.

What is it about the cultural context of African American families that might explain the function of authoritarian parenting and its impact on child outcomes? Most of the comparative research that has been conducted on parenting typologies has failed to address this issue. Some evidence is offered, however, in research by Steinberg, Dornbusch, and Brown (1992) in which parenting styles were assessed in a sample of adolescents of various ethnic backgrounds. Findings suggested that, depending on ethnicity, there are differences in the impact of an authoritarian parent style. Specifically, authoritative parenting and peer support for academic achievement served a protective function for academic achievement among European American students. Among Asian American students, however, peer support seemed to offset the negative consequences of authoritarian parenting; thus, authoritarian parenting in itself was not necessarily a risk factor. Among African American students in this sample, authoritative parenting was not associated with academic achievement in the absence of peer support for achievement, suggesting that parenting styles may function differently depending on family ethnicity (Steinberg et al., 1992). Later in this article, we discuss the role of cultural and socioeconomic influences on academic socialization.

\section{Home Learning Environment}

Another common approach to research in the "what parents do" tradition focuses on the home environment that parents provide for their children. Most research on the home learning environment focuses on the quality of language stimulation provided in the home or parental use of explicit literacy-promoting behaviors (Christian, Bachnan, \& Morrison, 2001). Interesting work conducted by Hart and Risley (1995) showed that the gap in vocabulary development between children of higher and lower socioeconomic status during the first 3 years of life was in large part attributable to differences in the amount of talking and interacting with the child by parents. Although some difference in the richness of utterances was found between the higher and lower socioeconomic status groups, the most striking differences occurred in the overall amount of speech taking place or failing to take place (Hart \& Risley, 1995).

The quality of children's home environments is frequently assessed through the use of observational techniques in which trained data collectors rate the general quality of the home setting and parent interactions with children. The Home Observation for Measurement of the Environment Scale (HOME; Caldwell \& Bradley, 1984) is perhaps the most frequently used tool for conducting such assessments. Several versions of the HOME have been developed to assess home environments and parent behaviors among children of different developmental periods. Depending on the child's age, the HOME includes subscales tapping a variety of parent behaviors that influence children's cognitive and social growth, including provision of learning materials, language and learning stimulation, variety in experience, and active stimulation (Bradley, 1994). Correlations between the HOME and measures of children's developmental status and intelligence have been shown to be in the low to moderate range (.20 to .60) during the first 2 years and the moderate range (.30 to .60) from the ages of 3 to 5 years (Bradley, 1994).

In addition to general observations of parents in the home setting, the explicit use of literacypromoting behaviors has been quantified through a number of paper-and-pencil measures. One measure developed by Griffin and Morrison (1997) contains literacy-related items such as the number of magazine or newspaper subscriptions in the household, the frequency of library card use, the number of books the child owns, and the frequency of parents' own reading activities.

Numerous studies support the influential roles that various features of children's home literacy environments play in shaping a variety of outcomes, including vocabulary skills in the early years and later reading achievement and academic skills (Christian, Morrison, \& Bryant, 1998; de Jong \& Leseman, 2001; Purcell-Gates, 1996; Senechal, LeFevre, Hudson, \& Lawson, 1996; Whitehurst \& Lonigan, 1998). Some 
studies incorporate information about parents' expectations for their child's academic performance, parental assistance with homework, and parental participation in intervention programs that are designed to bolster children's academic readiness (Parker, Boak, Griffin, Ripple, \& Peay, 1999). Home learning environments that include parental assistance with homework, availability of play materials, and parents who understand the role of play have been shown to predict greater school readiness among preschoolers. For example, improvements in parents' understanding of the role of play, in addition to parents' ability to facilitate their children's learning, have been associated with more positive behavioral outcomes such as increased creativity, curiosity, and independence in the classroom.

Children who face an increased risk of academic problems may be especially likely to benefit from positive home literacy environments. Ethnic and language minority children, immigrants, and children from low-income families have been identified in numerous research studies as being at risk for lower academic achievement and lower levels of literacy and other school-related skills at school entry. Some research suggests that general literacyrelated behaviors (e.g., library trips and daily reading) may be more effective in increasing literacy among these populations than more specific school tasks such as homework (Auerbach, 1995). In addition, it has been shown that children of working-class, less educated mothers who have a good family literacy environment have higher levels of literacy than children whose mothers are better educated but engage in fewer literacy-promoting activities with their children (Christian et al., 1998).

In addition to setting expectations for academic performance and behavior in school, parents may also socialize children about school through the type of caregiving environment that characterizes the home. The processes that parents use to shape children's environments include provision of sustenance, stimulation, support, structure, and surveillance (Bradley, 1995). These processes may be thought of as being active ways in which parents influence children's environments, but deficits in the quality or quantity of these processes are also critical. Children's environments derive meaning from what they contain as well as what they lack (Bradley, 1995). Many educational institutions recognize the importance of a child's caregiving environment in shaping physical growth, cognitive development, and socioemotional functioning (Kalesnik, 1999) and are working toward building partnerships between schools and families (Mangione \& Speth, 1998). In addition, continuities and discontinuities in children's early care environments have received increased attention in recent times as a major factor in children's transition into formal school settings (Moles, 1993; Rimm-Kaufman \& Pianta, 1999).

Many specific features of the home environment are influential in shaping child outcomes. One such feature is the communication style used by parents. The ways in which parents interact with their children greatly affect later social competencies (Maccoby \& Martin, 1983), and reflection-enhancing communication is considered to be an especially effective form of parent-child communication. In this type of communication, parental messages encourage children to think about the causes and effects of their actions. These messages enable the child to engage in processing how an action emerges from, and also serves to create, the affective and psychological environment that follows the action (Applegate, Burleson, \& Delia, 1992). Parents engage in explicit encouragement of reflection when they encourage their children to think about causes and consequences of their behavior as explicitly stated by the parents. After children examine the causes and consequences of their behavior, they will be able to modify that behavior. The following is an example that demonstrates parental use of reflection-enhancing communication with a child who is struggling with how to respond to a problem with a friend:

\footnotetext{
When people hurt us we want to call them names. It doesn't do any good though. Next time why don't you tell them you're angry at what they did. Then maybe they won't do it again. If they do, then just don't play with them. Just calling someone a name doesn't make you feel better or your friend. (Applegate et al., 1992, p. 16)
}

Reflection-enhancing communication refers to the degree to which the parent provides reasons that involve psychological consequences to inspire children to change or understand their behavior. In the school setting, the ability of children to modify their own behavior and to understand the behaviors of others has clear 
implications for social competence. The literature is replete with information about the critical role of social competence in shaping children's school success (e.g., Denham et al., 2001; Eisenberg \& Fabes, 1998; Saarni, 1999), thus making it important for parents to engage in positive communication styles with children that can promote social competence.

Whereas reflection-enhancing communication is inductive and therefore appeals to the child's internalized beliefs, the alternative type of communication style would be power assertive (Wilson, Cameron, \& Whipple, 1997). The power-assertive style relies on coercion to direct the child to change the behavior in question. Studies have suggested that power-assertive communication is associated with more aggression in children, whereas inductive communication is associated with altruism and the internalization of moral principles (Maccoby \& Martin, 1983). Reflection-enhancing communication has been described as complex behavior that promotes the development of more advanced behaviors and thought processes, such as perspective-taking skills, reasoning, and logic (Applegate et al., 1992), as well as positive peer relationships and psychological well-being (Wilson, Whipple, \& Grau, 1996). A home environment characterized by a reflection-enhancing communication style is an important protective factor for children making the transition to school.

\section{Transition Practices}

An extension of the home environment literature focuses on the use of specific behaviors to ease a child's transition to formal school. Studying transition practices is a relatively recent perspective in the research literature, but one that holds great promise for understanding how connections between the family and school settings shape children's school-related outcomes, including academic achievement and social competence. The National Center for Early Development and Learning undertook a massive study of children's transition to kindergarten, including an in-depth look at the use of transition practices by teachers and barriers to the use of such practices (see Pianta, Cox, Taylor, \& Early, 1999). Findings from this study and other studies suggest that contextual factors such as neighborhood poverty level and family ethnicity influence children's transition to school and that these early experiences may set the tone for future relationships between the child's family and school.

Teachers alone do not determine the nature of children's transition to formal school. Although transition practices such as letters to parents, telephone calls to the child, and open houses in which the family may visit the child's new classroom are ways in which teachers and schools may facilitate the transition to school (Pianta et al., 1999), parent transition practices are also of critical importance. One may think of parental use of transition practices as a formal way of describing behaviors that are designed to prepare children for starting school. Such behaviors include many activities identified as promoting children's school readiness and early academic success, including reading to the child, practicing counting, and so forth. Continued research is needed on how parents' use of transition practices relates to children's early academic and behavioral outcomes.

After children complete the transition to the school setting, parents continue to play a critical role in early academic experiences. In the research literature, a major focus is on understanding the way in which parental involvement in children's early school experiences influences child outcomes. Next, we briefly review this literature and discuss some novel approaches to conceptualizing and measuring parental involvement.

\section{Parental Involvement}

Parental involvement in a child's education is one of the key mechanisms through which children are socialized for academic success. Scientists and practitioners from a variety of disciplines have investigated factors related to parental involvement. Recently, a special issue of School Psychology Review (Fantuzzo, Doll, Greenfield, \& Slaughter-Defoe, 1999) was dedicated to issues related to parental involvement in schools. Books such as that of Ryan and colleagues (Ryan, Adams, Gullotta, Weissberg, \& Hampton, 1995) have become practical guides for understanding how family-school partnerships promote school success. Epstein's (1995) framework identifies six specific types of involvement activities that connect families and schools, thereby promoting positive academic experiences for children: parenting, com- 
munication, volunteering, learning at home, decision making, and connections with the community.

Parental involvement in children's academic lives is a well-recognized critical factor for children's success in school. Two major approaches to understanding parental involvement are represented in the research literature. First, certain sociodemographic characteristics have been shown to relate to the likelihood of parents being involved with schools. Correlates of parental involvement such as socioeconomic status and ethnicity have been associated with a lower likelihood of overall parental involvement in the education of children (Griffith, 1998; Gutman \& Eccles, 1999; National Center for Education Statistics, 1998a, 1998b; Reynolds, Weissberg, \& Kasprow, 1992).

The second major approach to understanding parental involvement focuses on parental perceptions, attitudes, and beliefs about schools and how these factors relate to involvement. Parents' perceptions, attitudes, and beliefs are based largely on their feelings and emotions, which are powerful influences on child-rearing practices and may determine adaptive or maladaptive parenting strategies (Dix, 1991, as cited in Thompson, 1993). How parents feel about school and their own emotional connections to school settings may drive the kinds of academic socialization practices they engage in with their children. Parents with more positive feelings about school may be more likely to be involved than parents whose feelings are disorganized or negative (Hoover-Dempsey \& Sandler, 1997).

A school atmosphere that is open, trusting, and inviting is conducive to building healthy relationships among children, their families, and the school setting (Christenson \& Sheridan, 2001). Characterized by both tangible and intangible qualities, a school's atmosphere, or climate, has been shown to relate to levels of parental involvement (Christenson \& Sheridan, 2001; Esposito, 1999). A study of first and second graders from low-income urban areas revealed that parental perceptions of school climate significantly predicted children's math and reading achievement scores and social skills (Esposito, 1999). Other research suggests that parental "constructs of development," or what parents view as truths about the nature of children, also influence child outcomes (McGilli-
cuddy-DeLisi, 1992). This is especially important for academic outcomes, because relationships between parental beliefs about children's academic achievement and children's academic outcomes have been demonstrated (McGillicuddy-DeLisi, 1992). Children's academic outcomes are determined, in part, by parental perceptions, attitudes, and beliefs about schools and academic achievement.

The reason that so much attention has been focused on identifying predictors and correlates of parental involvement is that increased parental involvement has been consistently linked with more positive school experiences and better academic outcomes for children (Christenson, Hurley, Sheridan, \& Fenstermacher, 1997; Christenson, Rounds, \& Gorney, 1992; Entwisle, Alexander, \& Olson, 1997; White, Taylor, \& Moss, 1992). Moreover, finding ways to promote parents' involvement in the early educational experiences of their children may enhance parents' perceptions of their own selfefficacy (Bandura, Barbaranelli, Caprara, \& Pastorelli, 1996). This may in turn facilitate the establishment of relationships among parents, teachers, and schools and thus promote children's long-term academic success. Building partnerships and fostering effective communication and interaction between the home and school settings increase the likelihood for academic achievement and promote continuity across settings (Mangione \& Speth, 1998; Pianta \& Walsh, 1996; Smith et al., 1997).

Results from several intervention programs suggest that increased levels of parental involvement in school are associated with children's academic readiness and early academic achievement (Epstein \& Dauber, 1991; Lopez \& Cole, 1999; Miedel \& Reynolds, 2000; Reynolds, Mavrogenes, Bezruckzo, \& Hagemann, 1996). In 1998, the National Standards for Parent/Family Involvement Programs (National PTA, 1998, 2000) were developed, providing a set of guidelines to be used by schools and families to implement parental involvement strategies. These policy guidelines were shaped in large part by research suggesting positive relationships between parental involvement and children's academic success.

Parental involvement, the home learning environment, and the use of school transition practices are keys in parents' attempts to promote school success for their children. As concluded 
by Kellaghan and colleagues (1993, as cited in Christenson et al., 1997), "what parents do" in relation to their children's education is more important than "who they are." Nevertheless, much of our understanding of sociodemographic influences on child outcomes is viewed from the perspective of "who parents are."

\section{The "Who Parents Are" Perspective}

In contrast to focusing on parental behaviors, the "who parents are" perspective posits traitlike explanations for why parents socialize their children in particular ways. One may conceptualize the transmission of values and attitudes about school as largely an environmental phenomenon, but genetic relatedness between parent and child contributes to children's cognitive abilities, in turn affecting their school success or failure.

To our knowledge, no research has been focused directly on providing an understanding of genetic influences on children's academic socialization, but some studies in recent years have demonstrated the genetic and environmental contributions to children's cognitive and social outcomes. These models provide important information about how genetic and environmental influences on child outcomes can be estimated (e.g., Jacobson \& Rowe, 1999; Neiderheiser, Pike, Hetherington, \& Reiss, 1998). Great advances have been made in understanding genetic contributions to cognitive development and specific problem behaviors that occur in school settings, but less is known about the factors that shape attitudes and values about school.

\section{Socioeconomic and Cultural Influences}

As noted earlier, socioeconomic and cultural influences on child socialization are sometimes translated into social address variables that are used in research studies and are proxies for complex interactions across the various contextual systems that affect development. A plethora of research studies include variables such as race and poverty status as predictors of parenting and child outcomes. Although such social address variables provide information about group similarities and differences, this approach does not allow for the process of socialization to be understood. Moreover, this approach pro- vides no information about within-group differences and protective mechanisms that may promote resilience under conditions of risk. Today, there are numerous examples of research studies that go beyond the use of social address variables to explain group differences by attempting to describe the mechanisms through which socioeconomic characteristics, ethnicity, or culture translate into academic socialization.

Evidence suggests that variability exists across sociocultural groups in terms of particular expectations for child development such as weaning and sleeping with parents (Morelli, Rogoff, Oppenheim, \& Goldsmith, 1992). Similarly, there are several lines of research delineating the ways in which economic and cultural influences shape parental cognitions related to school (e.g., Gutman \& McLoyd, 2000; Stevenson \& Lee, 1990). In one study of cultural models of school achievement, it was found that immigrant Latino parents believed that children reach the "age of reason" at approximately 5 years, and therefore few parents believed in engaging in reading with their children before this age (Gallimore \& Goldenberg, 2001). In the same study, interviews with parents showed that rather than emphasizing children's emergent literacy, the cultural perspective of these parents emphasized the importance of children's moral development. That is, early reading activities were viewed as being of relatively low priority in comparison with teaching children good manners and the difference between right and wrong (Gallimore \& Goldenberg, 2001). Rather than making broad generalizations about immigrant Latino parents not valuing reading to young children, it would be more culturally sensitive to attempt to understand what such parents do value and to gather information about how others view what we would consider standard mainstream values (e.g., reading to young children; Eccles \& Harold, 1996). This way, culturally informed strategies for promoting positive outcomes for children in school settings can be developed. The findings of Gallimore and Goldenberg (2001) provide an excellent example of how cultural beliefs may inform the academic socialization of children.

\section{Parental Cognitions About School}

An important aspect of the "who parents are" perspective involves the ways in which parents 
think about their children's academic outcomes. We contend that parental cognitions about children's academic achievement are a product of individual parent characteristics and environmental characteristics. These characteristics influence parenting behaviors related to children's school experiences. Borrowing from other key issues in developmental psychology such as meta-cognition and meta-emotion, our conceptual model proposes that parents' cognitions about school influence the way they socialize their children. Just as meta-cognition involves thinking about thinking and meta-emotion involves thinking about emotional development, it makes sense that how parents think about school will translate into specific behaviors. Understanding parental cognitions about school and the role of expectations for children's academic achievement is a key facet of the construct of academic socialization.

Parents influence children's school-related behaviors and outcomes through their expectations for achievement. Much of the research evidence for the connection between expectations for achievement and children's academic outcomes has focused on adolescents from various ethnic groups (e.g., Chen \& Lan, 1998; Goyette \& Xie, 1999; Reynolds \& Gill, 1994; Smith-Maddox, 1999; Taylor, Hinton, \& Wilson, 1995). A few studies have focused specifically on how parental expectations for achievement influence outcomes for younger children (see Richman \& Rescorla, 1995; Wentzel, 1998), including children of ethnically diverse backgrounds (Entwisle \& Alexander, 1996; Okagaki \& Frensch, 1998), and how these early expectations affect outcomes throughout children's school careers (Hess, Holloway, Dickson, \& Price, 1984). Retrospective accounts of parental expectations for academic achievement have been linked to more positive adult outcomes, including financial success, suggesting that higher expectations for school achievement have effects that may last through adulthood (Hill, 1997). This body of research suggests that parental expectations for school success translate into better academic performance for children, underscoring the importance of parental attitudes in shaping children's early school experiences.

\section{Individual Experiences}

In addition to biological influences, contextual influences such as socioeconomic charac- teristics and culture, and parent cognitions about school, individual experience is another important factor to consider in understanding academic socialization. For example, a young child living in a neighborhood with high rates of crime and violence may be indirectly affected by these contextual influences. However, if his or her mother has been the victim of a violent assault, what might otherwise be considered a contextual influence (i.e., neighborhood violence) takes on new meaning. Parenting behaviors also may be directly affected by individual experiences.

\section{Intergenerational Influences}

Thinking about children's academic socialization in terms of intergenerational influences provides a way to combine the "what parents do" and "who parents are" perspectives. To date, the issue of how children's academic experiences and school outcomes are influenced by transgenerational processes has received little consideration. It makes sense, however, that the kinds of experiences parents had during their many years of first-hand exposure to school settings will affect the way they view school and academic outcomes (Eccles \& Harold, 1996). We contend that parents' own experiences in school are important considerations in understanding children's academic socialization.

Several areas of research and theory provide support for the notion that parents' own experiences in school may be an important factor in understanding parenting behaviors related to children's education. It has been suggested that childhood memories are "reactivated" as parents prepare their own children for similar experiences (Putallaz, Costanzo, \& Klein, 1993) and that parents use recollections of their own childhood experiences to interpret and direct their children's experiences (Putallaz, Costanzo, \& Smith, 1991). Parents who characterize their school experiences as warm, positive, and supportive may have an internal "working model" according to which schools are positive places for their children. In contrast, parents who characterize their school experiences as negative and thus view schools as hostile, unfair, or rejecting may have negative "working models" of school. These working models provide a foundation for the academic 
socialization of children. Given that the majority of parents have spent many years in school, recollections of parental experiences in school are likely to have a strong effect on the academic socialization of children.

An intergenerational influences perspective is evidenced in several areas of research that detail how the attitudes and behaviors of one generation affect other generations. Studies have demonstrated the transgenerational effects of less optimal parent-level dynamics (e.g., marital conflict) on child outcomes, including studies involving cross-sectional research designs (Dadds, Atkinson, Turner, Blums, \& Lendich, 1999) as well as longitudinal designs (Cowan, Cohn, Cowan, \& Pearson, 1996). Additional support is provided by longitudinal data from a four-generation research study conducted by Elder, Caspi, and Downey (1986) in which it was found that parenting characteristics from one generation influenced parent-child relationships, in turn influencing the parenting behaviors of the children once they reached adulthood. Whitbeck et al. (1992) found a pattern of continuity across generations in terms of parental depressed affect and parental rejection. Evidence suggests that there is intergenerational continuity of psychological characteristics between parents and children across a variety of domains ranging from aggressive behavior to moral values (Holden \& Zambarano, 1992). This is not to say that children are doomed to repeat the behavioral patterns of their parents, but there is considerable evidence confirming continuities in certain behaviors across generations.

\section{Effects on Children}

As noted previously, less than optimal parenting behaviors are linked to a variety of negative child outcomes. Perhaps the study of child abuse is the best example of how negative parenting behaviors can have a devastating impact on children's lives, affecting social development as well as academic outcomes.

Although transmission rates vary widely in terms of intergenerational child abuse and neglect, some studies estimate that $47 \%$ to $70 \%$ of mothers in high-risk populations (e.g., single mothers) who were physically abused as children currently abuse their own children (Egeland, Jacobvitz, \& Sroufe, 1988). Findings from retrospective and prospective studies of child abuse suggest linkages across generations that place children of abused parents at risk for being abused (Putallaz, Costanzo, Grimes, \& Sherman, 1998). In a study conducted by Egeland et al. (1988), almost $100 \%$ of parents who abused their children reported having been abused by their own parents. This alarmingly high figure suggests that understanding parents' own experiences with abuse is an important factor in understanding why some parents may be likely to abuse their children.

Social learning theory provides one explanation for the intergenerational transmission of less than optimal parenting practices. Abusive behavior may be modeled by parents such that their children are likely to learn these models and grow up to rely on them in handling difficult situations later in life (Hertzberger, 1983). Abused children may develop schemas about appropriate and inappropriate child behavior that surface during the transition to parenthood.

Attachment theory has also been asserted as an explanation for the intergenerational transmission of suboptimal parenting (Main \& Goldwyn, 1984). Evidence from research on attachment relationships across the life span suggests that experiences that parents have as children influence parenting behaviors with their own children. The finding that attachment classifications among parents are related to the attachment classification of their children is well supported in the research literature (Benoit \& Parker, 1994; Main, Kaplan, \& Cassidy, 1985; Putallaz et al., 1998; van Ijzendoorn, 1995). Parents' attachment classifications are also related to children's behavioral outcomes, including internalizing and externalizing behavior problems (Cowan et al., 1996). Insecure attachment relationships have been shown to be more common among abused children than among nonabused children, and research has revealed that mothers currently abusing their children report having had poor or impaired attachment to their own caregivers (Green, 1998). Children may construct working models that influence later attachment formation with their own children.

One of the most widely recognized tools for demonstrating continuity of attachment across generations is the Adult Attachment Interview (Main et al., 1985), which is used to interview parents about their attachment relationships 
during childhood. Respondents are classified into adult attachment categories on the basis of these recollections, and then these categories are compared with the attachment classifications of the children of the respondents. The findings from research using this instrument demonstrate intergenerational continuities suggesting that children's working models of attachment that are shaped during childhood affect later socialization (Main et al., 1985). Although some research challenges continuities in the specific classifications used to denote attachment relationships over time (e.g., Lewis, Feiring, \& Rosenthal, 2000), there is ample empirical evidence supporting the fact that working models for relationships affect socialization across generations.

Intergenerational continuities in attitudes and behaviors should not be viewed from a deterministic standpoint. Prospective studies suggest that parents who break the cycle and do not go on to abuse their own children possess certain protective characteristics that distinguish them from parents who do engage in abuse (Langeland \& Dijkstra, 1995). Lack of protective factors such as social and material resources may be the mechanism that is associated with the transmission of abuse across generations. Research on low-income mothers confirms this notion. Lack of social and material resources, the presence of stressors stemming from economic hardship, and a history of child abuse have been shown to account for the increased likelihood of low-income mothers abused as children becoming child abusers themselves (Hall, Sachs, \& Rayens, 1998). Other research suggests that some parents who were abused as children but do not abuse their own children report at least one supportive relationship during their childhood (Egeland et al., 1988), also highlighting the role of protective factors in preventing the intergenerational transmission of child abuse.

Within the context of the family, experiences from one generation influence outcomes for the next. Research on child abuse and attachment relationships confirms this idea. Within the context of the school setting, it is also likely that the experiences of one generation may influence the experiences of the next. Studies of children's peer relationships within the school setting support this contention. Parents' memories of their childhood peer relationships have been shown to relate to their children's peer relationships. In a sample of preschool mothers, Putallaz et al. (1991) found that parents could be categorized into three groups in terms of the patterns of their recollections regarding peer relationships. The first group recalled generally positive and warm peer relationships, the second group recalled generally negative peer relationships, and the third group recalled having lonely, anxious peer experiences (Putallaz et al., 1991).

Interestingly, teacher, peer, and observer ratings of child social competence were highest for children whose mothers reported lonely-anxious peer recollections. Using attachment theory as a conceptual framework to explain this finding, the authors suggested that the lonely-anxious mothers operated from an internal locus of control. Thus, their parenting practices involved actively building a sense of empowerment and social efficacy in their children (Putallaz et al., 1993). These parents took an active role in shaping their children's social worlds so as to prevent their children from experiencing the types of peer relationships they experienced in their own childhood. In contrast, it was suggested that mothers who had generally negative peer recollections maintained socially distant relationships as a way to protect themselves from the pain of the social rejection experienced in childhood (Putallaz et al., 1993). The behavior of the mothers in this group would probably reflect an attitude that relationships are negative, thus leading to children being socialized in ways that are associated with less social competence. Indeed, children of this group of mothers were perceived as being the least socially competent (Putallaz et al., 1993).

The model proposed by Putallaz and colleagues may be generalized to derive an understanding of the transmission of attitudes and beliefs about school. That is, parents' own experiences in school may determine their beliefs, attitudes, and values related to school and academic achievement, and the transmission of these values is what defines the academic socialization of children. New research is testing relationships between parents' recollections of their own school experiences and children's social and academic outcomes in kindergarten (Clayton \& Taylor, 2001).

Certain school experiences, such as experiences of racial discrimination or devaluation, may be of particular consequence to the aca- 
demic socialization of parents from ethnic minority groups (Colbert, 1999). In a study of African American mothers of kindergartners, Rowley and Grace (2000) found that, over and above the effect of current perceptions of discrimination, mothers who believed that their teachers had discriminated against them on the basis of their race were less likely to be involved and had less positive involvement experiences. Rowley and Grace also found that even general memories of school as being supportive and interesting were positively related to involvement. Thus, the unique experiences of parents of color may also influence their current academic socialization strategies.

The accuracy or inaccuracy of parents' recollections of their school experiences may lead to questions about how early experiences shape later socialization practices. Although actual events and experiences are important, we posit that the nature of the recollection should be the unit of analysis, rather than the accuracy of the recollection per se. As suggested in studies of child abuse (Egeland et al., 1988), accuracy regarding the details of the event may be less influential than the individual's feelings and recollections about the event. Similarly, research on adult attachment classifications is based on adult recollections of experiences from childhood (Main et al., 1985). The way in which events are recalled provides fruitful ground for understanding parental socialization practices. Nevertheless, prospective longitudinal studies of the intergenerational transmission of achievement need to be conducted to prevent the limitations inherent in use of retrospective reports (e.g., forgetting, distorting, and interpreting the past in light of the present; Cairns, Cairns, Xie, Leung, \& Hearne, 1998).

\section{A Model of Academic Socialization}

The conceptual model we propose depicts the process of academic socialization. Parents, through their individual experiences, social and cultural characteristics, and behaviors, set the stage for their children's early academic experiences. In our model, intergenerational influences are represented by the way in which parents' own school experiences and cognitions about school shape their parenting behaviors. These behaviors may serve as important mediators of parents' experiences, providing the op- portunity for positive parenting behaviors to stifle the impact of negative experiences that parents may have had during their own years of formal schooling. Future research should be conducted to test for the mediating effects of the parent behaviors included in the present model, especially in cases in which parents may have had difficult school experiences. Additional mediating variables may also warrant investigation.

From a developmental perspective, the proposed model is appropriate for younger children. As children continue to mature physically, cognitively, and emotionally, other influences in addition to parent behaviors become increasingly important. Namely, peer influences are critical considerations in understanding the academic outcomes and social adjustment of adolescents. This does not negate the important role that parents play in shaping outcomes for adolescents. In fact, numerous studies have shown that parents continue to play a prominent role in shaping outcomes for adolescent children (Taylor, 1994). According to the conceptual model described here, it is likely that peer influences will play a more prominent role in the academic socialization of adolescents. Nevertheless, the role of parents in shaping the school experiences of adolescents must not be overlooked.

Children's early academic outcomes have been a subject of interest across multiple disciplines in recent years, in terms of research as well as social policy. Social policy efforts such as the 2000 national education goals and many state-level initiatives have also been implemented in an effort to promote early school success by focusing on parenting and parentchild relationships (Riley, 1996). In developmental psychology, there is growing recognition of the importance of studying the academic socialization of children, for the sake of understanding developmental trajectories for positive and negative child outcomes as well as understanding risk and protective factors for optimal parenting.

\section{References}

Applegate, J. L., Burleson, B. R., \& Delia, J. G. (1992). Reflection-enhancing parenting as an antecedent to children's social-cognitive and communicative development. In I. E. Sigel, A. V. McGil- 
licuddy-DeLisi, \& J. J. Goodnow (Eds.), Parental belief systems: The psychological consequences for children (pp. 3-39). Hillsdale, NJ: Erlbaum.

Auerbach, E. (1995). Deconstructing the discourse of strengths in family literacy. Journal of Reading Behavior, 27, 643-661.

Avenevoli, S., Sessa, F. M., \& Steinberg, L. (1999). Family structure, parenting practices, and adolescent adjustment: An ecological examination. In E. M. Hetherington (Ed.), Coping with divorce, single parenting, and remarriage: A risk and resiliency perspective (pp. 65-90). Mahwah, NJ: Erlbaum.

Bandura, A., Barbaranelli, C., Caprara, G. V., \& Pastorelli, C. (1996). Mechanisms of moral disengagement in the exercise of moral agency. Journal of Personality and Social Psychology, 71, 364-374.

Baumrind, D. (1989). Rearing competent children. In W. Damon (Ed.), Child development today and tomorrow (pp. 349-378). San Francisco: JosseyBass.

Baumrind, D. (1991). Effective parenting during the early adolescent transition. In P. A. Cowan \& E. M. Hetherington (Eds.), Family transitions (pp. 111-164). Hillsdale, NJ: Erlbaum.

Benoit, D., \& Parker, K. C. H. (1994). Stability and transmission of attachment across three generations. Child Development, 65, 1444-1456.

Blumer, H. (1956). Sociological analysis and the variable. American Sociological Review, 22, 683-690.

Bradley, R. H. (1994). The HOME Inventory: Review and reflections. In H. W. Reese (Ed.), $A d$ vances in child development and behavior (Vol. 25, pp. 241-288). San Diego, CA: Academic Press.

Bradley, R. H. (1995). Environment and parenting. In M. H. Bornstein (Ed.), Handbook of parenting: Vol. 2. Biology and ecology of parenting (pp. 235261). Mahwah, NJ: Erlbaum.

Bronfenbrenner, U. (1986). Ecology of the family as a context for human development: Research perspectives. Developmental Psychology, 22, 723742.

Bronfenbrenner, U. (1989). Ecological systems theory. In R. Vasta (Ed.), Annals of child development. Six theories of child development: Revised formulations and current issues (pp. 187-249). London: JAI Press.

Cairns, R. B., Cairns, B. D., Xie, H., Leung, M., \& Hearne, S. (1998). Paths across generations: Academic competence and aggressive behaviors in young mothers and their children. Developmental Psychology, 34, 1162-1174.

Caldwell, B., \& Bradley, R. H. (1984). Home Observation for Measurement of the Environment. Little Rock: University of Arkansas at Little Rock.

Chen, H., \& Lan, W. (1998). Adolescents' perceptions of their parents' academic expectations: Comparison of American, Chinese-American, and
Chinese high school students. Adolescence, 33, 385-390.

Christenson, S. L., Hurley, C. M., Sheridan, S. M., \& Fenstermacher, K. (1997). Parents' and school psychologists' perspectives on parent involvement activities. School Psychology Review, 26, 111130.

Christenson, S. L., Rounds, T., \& Gorney, D. (1992). Family factors and student achievement: An avenue to increase students' success. School Psychology Quarterly, 7, 178-206.

Christenson, S. L., \& Sheridan, S. M. (2001). Schools and families: Creating essential connections for learning. New York: Guilford Press.

Christian, K., Bachnan, H. J., \& Morrison, F. J. (2001). Schooling and cognitive development. In R. J. Sternberg \& E. L. Grigorenko (Eds.), Environmental effects on cognitive abilities (pp. 287335). Mahwah, NJ: Erlbaum.

Christian, K., Morrison, F. J., \& Bryant, F. B. (1998). Predicting kindergarten academic skills: Interactions among child care, maternal education, and family literacy environments. Early Childhood Research Quarterly, 13, 501-521.

Clayton, J. D., \& Taylor, L. C. (2001). Predicting children's problem behaviors, social competence, and developmental skills: An accumulated risk model. Unpublished master's thesis, University of South Carolina, Columbia.

Colbert, R. D. (1991). Untapped resource: African American parental perceptions. Elementary School Guidance and Counseling, 26, 96-105.

Cowan, P. A., Cohn, D. A., Cowan, C. P., \& Pearson, J. L. (1996). Parents' attachment histories and children's externalizing and internalizing behaviors: Exploring family systems models of linkage. Journal of Consulting and Clinical Psychology, 64, 53-63.

Dadds, M. R., Atkinson, E., Turner, C., Blums, G. J., \& Lendich, B. (1999). Family conflict and child adjustment: Evidence for a cognitive-contextual model of intergenerational transmission. Journal of Family Psychology, 13, 194-208.

de Jong, P. F., \& Leseman, P. P. M. (2001). Lasting effects of home literacy on reading achievement in school. Journal of School Psychology, 39, 389414.

Deater-Deckard, K., Dodge, K. A., Bates, J. E., \& Pettit, G. S. (1996). Physical discipline among African American and European American mothers: Links to children's externalizing behaviors. Developmental Psychology, 32, 1065-1072.

Denham, S., Mason, T., Caverly, S., Schmidt, M., Hackney, R., Caswell, C., \& DeMulder, E. (2001). Preschoolers at play: Co-socialisers of emotional and social competence. International Journal of Behavioral Development, 25, 290-301. 
Dix, T. (1991). The affective organization of parenting: Adaptive and maladaptive processes. Psychological Bulletin, 110, 3-25.

Eccles, J. S., \& Harold, R. D. (1996). Family involvement in children's and adolescents' schooling. In J. S. Eccles \& R. D. Harold (Eds.), Family-school links: How do they affect educational outcomes? (pp. 3-34). Hillsdale, NJ: Erlbaum.

Egeland, B. R., Jacobvitz, D., \& Sroufe, L. A. (1988). Breaking the cycle of abuse. Child Development, 58, 1080-1088.

Eisenberg, N., \& Fabes, R. A. (1998). Prosocial development. In N. Eisenberg \& W. Damon (Eds.), Handbook of child psychology: Vol. 3. Social, emotional, and personality development (5th ed., pp. 701-778). New York: Wiley.

Elder, G. H., Caspi, A., \& Downey, G. (1986). Problem behavior and family relationships: Life course and intergenerational themes. In A. B. Sorenson, F. Weinert, \& L. R. Sherrod (Eds.), Human development and the life course: Multidisciplinary perspectives (pp. 293-340). Hillsdale, NJ: Erlbaum.

Entwisle, D. R., \& Alexander, K. L. (1996). Family type and children's growth in reading and math over the primary grades. Journal of Marriage and the Family, 58, 341-355.

Entwisle, D. R., Alexander, K. L., \& Olson, L. S. (1997). Children, schools, \& inequality. Boulder, CO: Westview Press.

Epstein, J. L. (1995). School/family/community partnerships: Caring for children we share. Phi Delta Kappan, 76, 701-712.

Epstein, J. L., \& Dauber, S. L. (1991). School programs and teacher practices of parent involvement in inner-city elementary and middle schools. Elementary School Journal, 91(3), 289-305.

Esposito, C. (1999). Learning in urban blight: School climate and its effect on the school performance of urban, minority, low-income children. School Psychology Review, 28, 365-377.

Fantuzzo, J., Doll, B., Greenfield, D., \& SlaughterDefoe, D. (Eds.). (1999). Beginning school ready to learn: Parental involvement and effective educational programs [Special issue]. School Psychology Review, 28(3).

Gallimore, R., \& Goldenberg, C. (2001). Analyzing cultural models and settings to connect minority achievement and school improvement research. Educational Psychologist, 36, 45-56.

Gonzales, N. A., Hiraga, Y., \& Cauce, A. M. (1998). Observing mother-daughter interaction in AfricanAmerican and Asian American families. In H. I. McCubbin, E. A. Thompson, A. I. Thompson, \& J. A. Futrell (Eds.), Resiliency in African-American families (pp. 259-286). Thousand Oaks, CA: Sage.

Goyette, K., \& Xie, Y. (1999). Educational expectations of Asian American youths: Determinants and ethnic differences. Sociology of Education, 72, 2236.

Green, A. H. (1998). Factors contributing to the generational transmission of child maltreatment. Journal of the American Academy of Child and Adolescent Psychiatry, 37, 1334-1336.

Griffin, E. A., \& Morrison, F. J. (1997). The unique contribution of home literacy environment to differences in early literacy skills. Early Child Development and Care, 127-128, 233-243.

Griffith, J. (1998). The relation of school structure and social environment to parent involvement in elementary schools. Elementary School Journal, 99, 53-80.

Gutman, L. M., \& Eccles, J. (1999). Financial strain, parenting behaviors, and adolescents' achievement: Testing model equivalence between African American and European American single- and two-parent families. Child Development, 70, 464476.

Gutman, L. M., \& McLoyd, V. C. (2000). Parents' management of their children's education within the home, at school, and in the community: An examination of African-American families living in poverty. Urban Review, 32, 1-24.

Hall, L. A., Sachs, B., Rayens, M. K. (1998). Mothers' potential for child abuse: The roles of childhood and social resources. Nursing Research, 47, 87-95.

Hart, B., \& Risley, T. R. (1995). Meaningful differences in the everyday experience of young American children. Baltimore: Brookes.

Hertzberger, S. (1983). Social cognition and the transmission of abuse. In D. Finkelhor, R. Gelles, G. Hotaling, \& M. Straus (Eds.), The dark side of families: Current family violence research (pp. 317-329). Beverly Hills, CA: Sage.

Hess, R. D., Holloway, S. D., Dickson, P. W., \& Price, G. G. (1984). Maternal variables as predictors of children's school readiness and later achievement in vocabulary and mathematics in sixth grade. Child Development, 55, 1902-1912.

Hetherington, E. M., Henderson, S. H., \& Reiss, D. (1999). Adolescent siblings in stepfamilies: Family functioning and adolescent adjustment. Monographs of the Society for Research in Child Development, 64(4, Serial No. 259).

Hill, N. (1997). Does parenting differ based on social class?: African American women's perceived socialization for achievement. American Journal of Community Psychology, 25, 675-697.

Hill, S. A. (1999). African American children: Socialization and development in families. Thousand Oaks, CA: Sage.

Holden, G. W., \& Zambarano, R. J. (1992). Passing the rod: Similarities between parents and their young children in orientations toward physical punishment. In I. E. Siegel, A. V. McGillicuddy- 
DeLisi, \& J. J. Goodnow (Eds.), Parental belief systems: The psychological consequences for children (2nd ed., pp. 143-172). Hillsdale, NJ: Erlbaum.

Hoover-Dempsey, K. V., \& Sandler, H. M. (1997). Why do parents become involved in their children's education? Review of Educational Research, 67, 3-42.

Jacobson, K. C., \& Rowe, D. C. (1999). Genetic and environmental influences on the relationship between family connectedness, school connectedness, and adolescent depressed mood: Sex differences. Developmental Psychology, 35, 926-939.

Kalesnik, J. (1999). Family assessment. In E. V. Nuttall, I. Romero, \& J. Kalesnik (Eds.), Assessing and screening preschoolers: Psychological and educational dimensions (pp. 112-125). Boston: Allyn \& Bacon.

Kellaghan, T., Sloane, K., Alvarez, B., \& Bloom, B. S. (1993). The home environment and school learning. San Francisco: Jossey-Bass.

Langeland, W., \& Dijkstra, S. (1995). Breaking the intergenerational transmission of child abuse: Beyond the mother-child relationship. Child Abuse Review, 4, 4-13.

Lewis, M., Feiring, C., \& Rosenthal, S. (2000). Attachment over time. Child Development, 71, 707720.

Lopez, A., \& Cole, C. L. (1999). Effects of a parentimplemented intervention on the academic readiness of five Puerto Rican kindergarten students in an urban school. School Psychology Review, 28, 439-447.

Maccoby, E., \& Martin, J. (1983). Socialization in the context of the family: Parent-child interaction. In P. H. Mussen (Ed.), Charmichael's manual of child psychology (pp. 1-101). New York: Wiley.

Main, M., \& Goldwyn, R. (1984). Predicting rejection of her infant from mother's representation of her own experience: Implications for the abusedabusing intergenerational cycle. Child Abuse and Neglect, 8, 203-217.

Main, M., Kaplan, N., \& Cassidy, J. (1985). Security in infancy, childhood, and adulthood: A move to the level of representation. Monographs of the Society for Research in Child Development, 50(1, Serial No. 209).

Mangione, P. L., \& Speth, T. (1998). The transition to elementary school: A framework for creating early childhood continuity through home, school, and community partnerships. Elementary School Journal, 98, 381-397.

McGillicuddy-DeLisi, A. V. (1992). Parents' beliefs and children's personal-social development. In I. E. Sigel, A. V. McGillicuddy-DeLisi, \& J. J. Goodnow (Eds.), Parental belief systems: The psychological consequences for children (pp. 115142). Hillsdale, NJ: Erlbaum.
Miedel, W. T., \& Reynolds, A. J. (2000). Parent involvement in early intervention for disadvantaged children: Does it matter? Journal of School Psychology, 37, 379-402.

Moles, O. C. (1993). Collaboration between schools and disadvantaged parents: Obstacles and openings. In N. F. Chavkin (Ed.), Families and schools in a pluralistic society (pp. 21-52). Albany: State University of New York Press.

Morelli, G. A., Rogoff, B., Oppenheim, D., \& Goldsmith, D. (1992). Cultural variation in infants' sleeping arrangements: Questions of independence. Developmental Psychology, 28, 604-613.

National Center for Education Statistics. (1998a). Factors associated with fathers' and mothers' involvement in their children's schools. Washington, DC: Author.

National Center for Education Statistics. (1998b). Parent involvement in school-related activities. Washington, DC: Author.

National PTA. (1998). National standards for parent/ family involvement programs. Chicago: Author.

National PTA. (2000). Building successful partnerships: A guide for developing parent and family involvement programs. Bloomfield, IN: National Education Service.

Neiderheiser, J. M., Pike, A., Hetherington, E. M., \& Reiss, D. (1998). Adolescent perceptions as mediators of parenting: Genetic and environmental contributions. Developmental Psychology, 34, 14541469.

Okagaki, L., \& Frensch, P. A. (1998). Parenting and children's school achievement: A multiethnic perspective. American Educational Research Journal, 35, 123-144.

Parker, F. L., Boak, A. Y., Griffin, K. W., Ripple, C., \& Peay, L. (1999). Parent-child relationship, home learning environment, and school readiness. School Psychology Review, 28, 413-425.

Pianta, R. C., Cox, M. J., Taylor, L. C., \& Early, D. M. (1999). Kindergarten teachers' practices related to the transition into school: Results of a national survey. Elementary School Journal, 100, 71-86.

Pianta, R. C., \& Walsh, D. J. (1996). High-risk children in schools: Constructing sustaining relationships. New York: Routledge.

Purcell-Gates, V. (1996). Stories, coupons, and the TV guide: Relationships between home literacy experiences and emergent literacy knowledge. Reading Research Quarterly, 31, 406-428.

Putallaz, M., Costanzo, P. R., Grimes, C., \& Sherman, D. (1998). Intergenerational continuities and their influences on children's social development. Social Development, 7, 389-427.

Putallaz, M., Costanzo, P. R., \& Klein, T. (1993). Parental childhood social experiences and their effects on children's relationships. In S. Duck 
(Ed.), Understanding relationship processes: Vol. 2. Learning about relationships (pp. 63-97). New York: Sage.

Putallaz, M., Costanzo, P. R., \& Smith, R. B. (1991). Maternal recollections of childhood peer relationships: Implications for their children's social competence. Journal of Social and Personal Relationships, 8, 403-422.

Reynolds, A. J., \& Gill, S. (1994). The role of parental perspectives in the school adjustment of inner-city Black children. Journal of Youth and Adolescence, 23, 671-694.

Reynolds, A. J., Mavrogenes, N. A., Bezruckzo, N., \& Hagemann, M. (1996). Cognitive and familysupport mediators of preschool effectiveness: A confirmatory analysis. Child Development, 67, 1119-1140.

Reynolds, A. J., Weissberg, R. P., \& Kasprow, W. J. (1992). Prediction of early social and academic adjustment of children from the inner city. American Journal of Community Psychology, 20, 599624.

Richman, E. R., \& Rescorla, L. (1995). Academic orientation and warmth in mothers and fathers of preschoolers: Effects on academic skills and selfperceptions of competence. Early Education and Development, 6, 197-213.

Riley, R. W. (1996). Improving America's schools. School Psychology Review, 25, 477-484.

Rimm-Kaufman, S., \& Pianta, R. C. (1999). Patterns of family-school contact in preschool and kindergarten. School Psychology Review, 28, 426-438.

Rowley, S. J., \& Grace, N. C. (2000, October). Reflecting upon racism: School involvement as a function of remembered discrimination in African American mothers. Paper presented at the Black Empirical Psychology Conference, Ann Arbor, MI.

Ryan, B. A., Adams, G. R., Gullotta, T. P., Weissberg, R. P., \& Hampton, R. L. (1995). The familyschool connection: Theory, research, and practice. Thousand Oaks, CA: Sage.

Saarni, C. (1999). The development of emotional competence. New York: Guilford Press.

Senechal, M., LeFevre, J., Hudson, E., \& Lawson, E. P. (1996). Knowledge of storybooks as a predictor of young children's vocabulary. Journal of Educational Psychology, 88, 520-526.

Smith, E. P., Connell, C. M., Wright, G., Sizer, M., Norman, J. M., Hurley, A., \& Walker, S. N. (1997). An ecological model of home, school, and community partnerships: Implications for research and practice. Journal of Educational and Psychological Consultation, 8, 339-360.

Smith-Maddox, R. (1999). The social networks and resources of African American eighth graders: Ev- idence from the National Educational Longitudinal Study of 1988. Adolescence, 34, 169-183.

Steinberg, L., Dornbusch, S. M., \& Brown, B. B. (1992). Ethnic differences in adolescent achievement: An ecological perspective. American Psychologist, 47, 723-729.

Stevenson, H. W., \& Lee, S. (1990). Contexts of achievement. Monographs of the Society for Research in Child Development, 55(1-2, Serial No. 221).

Taylor, L. C. (1994). Winning combinations: The effects of different parenting style combinations on adolescent adjustment. Unpublished master's thesis, University of Virginia, Charlottesville.

Taylor, L. C., Hinton, I. D., \& Wilson, M. N. (1995). Parental influences on academic performance in African American students. Journal of Child and Family Studies, 4, 293-302.

Thompson, R. A. (1993). Socioemotional development: Enduring issues and new challenges. Developmental Review, 13, 372-402.

van Ijzendoorn, M. H. (1995). Adult attachment representation, parental responsiveness, and infant attachment: A meta-analysis on the predictive validity of the Adult Attachment Interview. Psychological Bulletin, 117, 387-403.

Wentzel, K. R. (1998). Parents' aspirations for children's educational attainments: Relations to parental beliefs and social address variables. MerrillPalmer Quarterly, 44, 20-37.

Whitbeck, L. B., Hoyt, D. R., Simons, R. L., Conger, R. D., Elder, G. H., Lorenz, F. O., \& Huck, S. (1992). Intergenerational continuity of parental rejection and depressed affect. Journal of Personality and Social Psychology, 63, 1036-1045.

White, K. R., Taylor, M. J., \& Moss, V. D. (1992). Does research support claims about the benefits of involving parents in early intervention programs? Review of Educational Research, 62(1), 91-125.

Whitehurst, G. J., \& Lonigan, C. J. (1998). Child development and emergent literacy. Child Development, 69, 848-872.

Wilson, S. R., Cameron, K. A., \& Whipple, E. E. (1997). Regulative communication strategies within mother-child interactions: Implications for the study of reflection-enhancing parental communication. Research on Language and Social Interaction, 30, 73-92.

Wilson, S. R., Whipple, E. E., \& Grau, J. (1996). Reflection-enhancing communication: How do parents vary across misbehavior situations and child resistance? Journal of Social and Personal Relationships, 13, 553-569.

Received October 18, 2002

Revision received January 27, 2003 Accepted March 18, 2003 